\title{
Ship anchors in the Mediterranean from the Bronze Age to the Middle Ages: An analytical and experimental study
}

Menna-Allah Ibrahim Mouhammed Aboelatta 
PDF created with pdfFactory Pro trial version www.pdffactory.com 


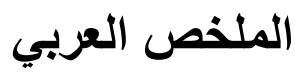

البحث يناقش المرساوات وتطورها في البحر المتوسط منذ العصر البرونزي حتي العصور

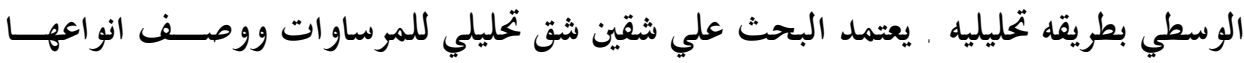
وصف دقيق وشق تجريبي سوف يتم شرحه لاحقا.

يعتمد البحث علي الجحانب التحليلي للمراسوات وتطورها حيــث ينــاقش تطــــورات

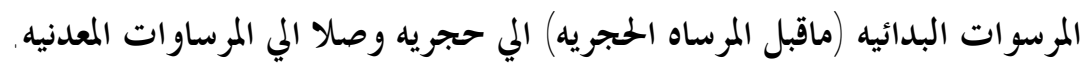

الجحانب التحليلي يشمل وصف لانواع المراسوات مع شرح بعض الامثله ابتـــداءا مـــــ المرساه الحجريه ذات الثقب الواحد الي المرساه الحجريه ذات التقبين وصولا لالي المبل المرساه الحجريه ذات الثلاث ثقوب وصف وشرح تفصيلي موضح كيفيه عمل كل نوع فيهم والظروف الجويه والبيئيه المناسبه لكل نوع.

ويشمل البحث ايضا وصف تحليلي للمرساوات الخشبيه والختويه علي معادن وصولا الي المرساوات المعدنيه.

يناقش البحث ايضا القيمه الرمزيه للمرســاوات مــن اول المرســاوات النذريسـه الي المرساوات كرمز من رموز الديانة المسيحية.

يشمل البحث دراسه تجريبيه للمرساوات الحجريه حيث سوف يتم عمل نموذج بـــائي للمخطاف الحجري بانواعه المختلفه حيث سوف يتم عمل نموذج للمرساه بثقب واحد لئد ومرساه بثقبين ومرساه بثلاثه ثقوب وسوف يكونوا في نفس الحجم و الوزن ولكن سوف يتم تجريبتهم في احوال جويه مختلفه وانواع قاع بحر مختلفه (رمليه - صخريه). لكن ماسوف يتم نشره هو الجزء المتعلق بالمرساوات الحجريه وانواعها وتطورها 
PDF created with pdfFactory Pro trial version www.pdffactory.com 


\section{Abstract}

The research discuss the ship anchor in the Mediterranean from the bronze age to the Middle Ages "an analytic study and an experire nt al study"

The research discuss analytic study for anchors and its development from the pre stone anchor to the metal anchors

The research also discuss the symbolic value of the ship anchors and contains an experimental study for the three shapes of the lime stone anchors.

But what will be publish in this paper is the stone anchor part.

Stone anchors were, almost certainly, the earliest type of anchor to be used, and contiued in use for a very long tin indeed there are some types that are in use today. For this reason the datig of stone anchor $s$ is ime nsel y d ffilt. Ay dated examples are, potentid ly of cons i cer abl e i m or tance so it is vital that any datig i if or ma tion be recorded. Nos $t$ stone anchors are, in fact, composite anchors, in which the stone provided the weight to take the anchor to the sea bed, whilst the holding power was provided by means of separate arms, usually made of wood. Should any trace of the arms survive this too needs to be recorded. Complete wooden anchors may be found, they come in a variety of shapes and forms. They should be photographed and measurements taken.

There is plenty of evidence that objects have been reused as stone anchors and fishi ry $i$ ght $s$. Thi s ra st becogni zed as it could lead to problems when it comes to ascribing a date 
to an anchor, or recognizing an object as an anchor. Quern and mill stones can be recycled as anchors, so the discovery of such a stone on the sea bed need not be evidence of it having been carried as cargo.

\section{Types of stone anchor}

No hole:A stone anchor without a hole drilled though it. It may have a groove cut around it (waisted). Stones of this type were sometimes used to weigh down a wooden anchor. Small versions were used as fishing weights and larger versions as buoy weights. Worked rectangular and rounded versions are known, as well as those based on an un-worked stone.

One hole: A stone anchor with a single hole though it. Also sometimes used to weigh down a wooden anchor. Smaller versions (maximum length $30 \mathrm{~cm}$, weight less than $10 \mathrm{~kg}$ ) are used as net-weights and very small examples (maximum length $12 \mathrm{~cm}$, weight less than $500 \mathrm{~g}$ ) as line-weights (dimensions taken from British examples).

Central hole: They can be found with a central hole these are sometimes called 'ring anchors'. Quern and mill-stones can be recycled as anchors of this type. In eighteenth century Yorkshire, worn out mill stones were used as buoy anchors.

Variations are known with smaller holes at the edge, either to attach the stone to a wooden anchor, or for a smaller rope to help in handling the anchor

Hole at end :Single hole anchors are also found with a hole at one end: these are the earliest known forms of stone anchor, examples have been found in the eastern Mediterranean dated to the second millennium B.C. These have continued in use 
until the present day, and are one of the most common type of fishing weight. Variations are known with an additional hole drilled into the top of the stone, linking with the main hole. This is believed to have been for securing additional ropes to aid recovery and prevent loss.

Two holes :This type of anchor has two holes, one at each end of the stone. These anchors could be used in two ways, both of which are known from recent ethnographic examples. In the first example, one hole took a rope, the other an arm - usually of wood. In the second, only recorded on fishing gear, both holes took ropes. Wear-patterns on the stone should make it possible to distinguish which method was used.

Classical:This anchor was commonly used in the Mediterranean by both Greek and Roman shipping, though plenty of examples are know from the Atlantic, Red Sea and Indian Ocean. It is often referred to as a 'classical' or 'Roman' anchor, although evidence suggests that it continued in use for many centuries after the end of the Roman Empire. The holes form a triangle. The upper hole, which took the rope, can either be in the same plane as the lower holes or it can run across the stone. There are usually two lower holes (though three are known), always in the same plane. Rough examples, on flat slabs of stone, are probably 'sand anchors' designed to lie flat on a sandy seabed to achieve maximum grip. 
PDF created with pdfFactory Pro trial version www.pdffactory.com 


\section{Introduction:}

Maritime archaeology is the study of the human interaction with the sea, lakes and rivers through the archaeological study of material manifestations of maritime culture, including vessels, shore side facilities, cargoes and even human remains. This wide definition may cause some confusion between \{underwater archaeology\} which describes the study of the past through any submerged remains and \{nautical archaeology\} which examines specifies of vessel construction and use, Delgado believes that maritime archaeology is a specialty part within underwater archaeology while nautical archaeology is a specialty within maritime archaeology (Delgado.1997.p.259). It should be noted as well that the primary object of the study is man because archaeology is not the study of objects simply for themselves but rather for the insight they give into the people who made or used them (Muckelroy, 1978, p. 4).

The importance of the anchor in the history of seafaring people is perhaps little understood. Yet, literally thousands of ships of war or commerce have been lost due to the failure of ground tackle, and the resultant loss of lives, vessels and cargo most probably had significant impact on the world. Despite this fact, it is incredible to note how little advancement was made 
in anchor design from the earliest Chinese anchors until just prior to World War II. The Greeks, the Romans, the Spanish, the English, and the other mariners would have handled their ships differently in exploration, in trade and in battle had they possessed anchors that could be trusted in bad weather. In fact, ship design itself would have been different had the concepts of modern anchor design been known

Each anchor found undersea represents the passage of a vessel ,hence its potential as a clue to that vessel's size and provenance(Frost,1997:25).the anchor is a wooden ,stone, or metal device that, when connected to a vessel with a cable or chain, was used to secure the vessel to the bed of a waterway to prevent it from drifting.(Steffy,2006:266) anchors are to a ship what brakes are to a car ; and just as a car needs brakes, a seagoing ship must carry some form of anchoring device the study of anchors is important to nautical archaeology for several reasons, an anchors on the seabed assumes the passing of a ship .Thus, if the anchor type belonging to a specific nationality can be defined, then finding a trail of that kind of anchor in the sea must signify a route used by ships of that nation. (Wachsmann, 1998:233). 


\section{What is the anchor?}

An anchor is a heavy object attached to a vessel by a cable or rope and cast overboard to keep the vessel in place either by its weight or by its flukes, which grip the bottom. Throughout time anchors had many shapes which could be chronologically classified. The earliest primordial shape, used by the ancient Greeks, were large stones or baskets filled with stones, which were lowered to the seabed by ropes. As ships grew larger more efficient anchors were required to hold them, and iron hooks designed to dig themselves into the seabed as any strain came upon them. A second arm to the hook making them double headed was added shortly afterwards. The Egyptians used a lead-weighted log. The Greeks are credited with the first use of iron anchors, while the Romans had metal devices with arms similar to modern anchors. The ordinary modern anchor consists of a shank (the stem, at the top of which is the anchor ring), a stock (the crosspiece at the top of the shank, either fixed or removable), a crown (the bottom portion), and arms, attached near the base of the shank at a right angle to the stock and curving upward to end in flat, triangular flukes. Other types of anchors include the patent anchor, which has either no stock at all or a stock lying in the same plane as the arms. (Modern ships have several anchors; usually there are two 
forward and two aft. Formerly made of wrought iron, anchors are now usually made of forged steel

Anchors could be viewed as a device used to hold a ship or other floating craft in place in an open area of water. Two kinds of anchor are distinguished: ship anchors and specialpurpose anchors. An anchor must be strong and easy to handle and must take and hold any ground well. Anchors may be described according to holding power, which is defined as the force that must be applied per unit of anchor weight to pull the anchor out of the ground when its shank is horizontal. The holding power depends on the design and weight of the anchor and on the type of bottom ground.

\section{Stone anchors development and use}

Stone anchors were, almost certainly, the earliest type of anchor to be used, and some types are still in use today. For this reason the dating of stone anchors is immensely difficult. Hence any dated examples are, potentially, of considerable importance. Most stone anchors are, in fact composite anchors, in which the stone provided weight to take the anchor to the seabed, while the holding power was provided by means of separate arms, usually made of wood, there may have been additional stones hung to help hold the anchor on the ground (Thoth, 2002). 
A heavy stone tied to a crude rope was man's first "anchor". <stone anchor> To tie the stone more securely, grooves were cut around the oblong shapes but they relied on weight alone for holding rather than hooking or burying as did later anchors. In order to extract usable archaeological evidence from this artefact category, one must find a basis for the typology and chronology of the composite stone anchors. Geological characterization seems to be an obvious choice, but many difficulties arise: It would be necessary to carry out analyses on the whole material, something which is quit impossible.

Thoth, 2002 found that, Pierced stones have been used for a variety of other purposes, including weights for fishing nets and for buoys and mooring, and some more unusual ones, such as driving fish into nets by beating them on the water. There is plenty of evidence that a variety of objects have been re-used as stone anchor such as an Ornament stonewhich had been found at Aswan in Egypt it was a statue base reused as stone anchor afterPuncture itfrom the middle, this must be recognized, as it could lead to problems when it comes to ascribing a date to an anchor. Quern and mill-stones could be recycled as anchors (Naish, 1985), so the discovery of such a 
stone on the sea-bed should not automatically lead to the assumption that it was being carried as cargo. (Frost, 1970).

So far, there is basic types of stone anchor have been recorded throughout the world. In many cases, anchors are made of either a naturally shaped stone, or a worked block.

The first anchor was used in early of no particular shape but sufficiently heavy and lashed to a rope. After the stone anchor with one hole appeared and took more than one shape like longish, oval and trapezoidal until finally they were additionally provided with one or two more holes for lodging wooden plugs pointed at both ends.

Even the Egyptians, with their expertise in engineering, still used conical stakes with papyrus cable in 2200 B.C. But anchoring was not as important as it would become, because early boats were small and always beached when not in use. As water travel increased, so too did the need for larger boats and better anchors.

The development of the stone anchor: Anchor Stones of no particular shape but sufficiently heavy and lashed to a rope (Fig. 6) were the first anchors for early craft, though not the only ones. Poles and branches to be stuck in the sea bed or loaded with stones were also used; they led to fixed mooring 
devices. Stones of shapes particularly suited for attaching a rope stimulated the development of stone anchors and stock anchors: From a stone with a hole (Fig. 7), more or less regularly shaped stone anchors took their form. They had at first only a single hole for the rope made in a marginal position (Fig. 7). Consequently these stone anchors came to have a more longish shape, becoming prevailingly oval or trapezoidal (Fig8). Finally they were additionally provided with one or two more holes for lodging wooden plugs pointed at both ends (Fig11anchor 5). By this, the simple weight anchor became a gripping stone anchor. This anchor, however, did not develop further. The occasional attempt to transform the stone into a sort of anchor shank (Frost, 1979: 158) had to fail since stone is not a suitable material for forming a shank which works as a lever when the anchor is lifted and its gripping arm breaks out of the seabed. Another development followed from longish stones to which the rope could safely be lashed at a central narrowing or cut (Fig. 11, anchor 6). Such anchor stones, besides their function as weight anchors, worked also as bulgy logs gripping between stones, rocks and other obstructions on the sea bottom. On a soft, flat bottom this anchor device would grip only after a hook had been lashed to it. The attachment of a bifurcating bough, the shorter leg of which formed the 
gripping arm, contributed to a surprising improvement; it transformed the anchor stone into a one-armed anchor with stone stock

\section{There were simple shapes of anchors before the default stone anchor shape:}

- The earliest form used by the ancient Greeks, were large stones or baskets filled with stones, which were lowered to the seabed by ropes (Darvill, 2009).Also the Viking used anchors usually made from stone lashed into a wooden frame (Fig 5).

Then this form developed to a stone anchor with different shapes: It can be classified according to the numbers of holes to:

Stone anchor without hole: these are stone anchors without a hole drilled through them. They may have a groove cut around them (waisted). Stones of this type were sometimes used to weigh down a wooden anchor. Small versions as fishing weights and larger version as buoy weights(Fig 1). Worked rectangular and rounded versions are known, as well as those based on an unworked stone. Sometimes the statue stone base had been reuse as an anchor such as Aswan anchor which had been found in the Nile(Fig 4).

Stone anchor with a single hole: these are stone anchors with a single hole through them. They were also sometimes 
used to weigh down a wooden anchor. Smaller versions (maximum length $30 \mathrm{~cm}$ (1ft), weight less than $10 \mathrm{~kg}$ (22lb)) were used as net weights and very small examples (maximum length $12 \mathrm{~cm}$, weight less than $500 \mathrm{gm}$ ) as line weights (Fig2).. There is another view for this stone anchor which is it may be a Stormy water stone anchor: because they hung from ships to act as additional ballast, or to help point the bow in a certain direction, they were small stone anchors with a single hole (Fig 3). I myself believe that it used as stormy water stone anchors.

\section{The anchor single hole place could be a variable so we can} find it as:

A central hole: these are sometimes called "ring anchors" Quren and millstones can be recycled as anchor of this type (Fig 7).

A hole in one end these are the earliest known forms of stone anchor, Examples have been found in the Mediterranean dated to the second millennium BC. These have continued in use until the present date, and are one of the most common type of fishing weight. Variations are known with an addition hole drilled into the top of the stone, linking with the main hole. This is believed to have been for securing additional roped to aid recovery and prevent loss (Thoth, 2002).

How the stone anchor work: the stone provided weight to take the anchor to the seabed. It was not working for the 
sandy seabed so they had to develop it to stone anchor with holes contain wooden stick which is the composite stone anchor.

\section{- Anchors have multi holes it is called Composite stone anchors:}

The Shape:Composite stone anchors are stone slabs with two or more holes drilled into them. One of these functions as a rope hole through, which the anchor cable is fixed. The other hole or holes are the tooth-holes in which a wooden bar is fixed to help in fastening the anchor to the seabed.

How composite stone anchor work: This class of anchors holds the ship not only by its weight, but also by the teeth hooked into the sea bottom. The idea, that these objects were used as "sand-anchors"” the study will talk about it later" (on sandy sea-floors). Is not supported by archaeological evidence: materials from several ports and anchorage sites demonstrate that both weights and composite anchors were used on the same sea floor types (Mc.caslin1980, 18-20).

The origin of the composite stone anchor: The earliest composite stone anchors were found in India and were connected with the maritime Activities of the Indus civilization.(Rao1965, 1969)The oldest archaeologically dated Mediterranean finds are from a LMIIIA2 galley found at 
Kommos and were made of Ugaritic or Cypriot stone. (Shaw.1995).It is probable that there is connection between the earlier Indian and the later Mediterranean developments. The Indus civilization was in close maritime contact with the Persian Gulf (Dilmun in Mesopotamia) in the third and early second Millennium BC. (Potts.1992)From the second quarter of the second Millennium, the focus of the Mesopotamian trade shifted from the Gulf-region to the North. Probably the idea of anchors with a composite structure arrived by this rearrangement to the Mediterranean (where only weightanchors were in use). Ugarit was the main port of trade in the Mesopotamian sphere of influence. Most probably, the first Mediterranean composite stone anchors were made there. The stone-analysis of the Kommos anchors strengthens this hypothesis.

\section{- Stone anchor with two holes:}

This type of anchor has two holes, one at each end of the stone .These anchors could be used in two ways, both of which are known from recent ethnographic examples. In the first example, a hole took a rope, the other an arm (usually of wood). In the second, only recorded on fishing gear, both holes took ropes. Wear patterns on the stone should make it possible to distinguish which method was used. Unfortunatelythere is a 
basic problem with stone anchors is their chronology (Frost, 1997).

\section{- Stone anchors with three holes:}

Three-holed stone anchors have been considered the earliest 'composite anchors', replacing single hole 'weight anchors' of the Bronze Age. Though there is inconclusive evidence as to the first appearance of this new, revolutionary type. The data from land sites attest its use by the end of the 13th century BCE. Specimens of this anchor have been used as a testimony for Iron Age maritime activity of the Phoenicians and related maritime groups at various sites. While three-holed stone anchors were found in clear medieval contexts, only a few originate from good datable contexts. Recent discoveries derive from both the well-stratified medieval urban settlement of Caesarea, and late deposits on its harbor floor. They include the period between1101 and 1265, when Crusaders settled in the city. This data calls for a revision of our attitude towards 'an-chorology' and a reassessment of earlier conclusions

concerning typology as a cultural and chronological benchmark (Raban,2000,260-272).

Three-hole stone anchors have been retrieved from the sea floor at and around the ancient harbors of Caesarea ever since underwater research commenced there in1960. ). 


\section{Three holed stone anchor variety:}

The more common form is an elongated rectangle, the height almost double the breadth. In some cases it is quite clear that the stone slab that was selected for perforation had been cut originally as a building ashlar, either for a wall or as a paving slab. An example which was eventually reused as a building stone and was found in situ within the wall of a building that was constructed some time during the second half of the 11th century CE. The stone was quarried from beach rock with a rather fine texture, indicating a beach within a semi-protected body of seawater, and thus probably local. The three piercings are roughly square, with 6-7 $\mathrm{cm}$ sides. Marine incrustation on the sides of the slab attests to its maritime function (Raban, 2000, 260-272).

All the anchors were apparently made of locally available bedrock, either beach rock or eolitic sandstone, known locally by its Arab name of kurkar. These types of sandy rock are often of a texture too crude to take a smooth finish. The only specimen in the group that was made of a fine-grain sandy limestone though found broken and with apertures roughly pierced in angular section, is of a smoothed and carefully fashioned rounded apical form, as if 
whoever curved it was particularly minded of aesthetics. Yet, one may argue that the present state of that anchor is the eventual product of centuries of abrasion by wave-carried sand (Raban,2000,260-272).

The sizes and the weights of the various anchors from medieval Caesarea vary from less than $20 \mathrm{~kg}$ to more than $100 \mathrm{~kg}$. Such variation may indicate that the maritime vessels for which these anchors were made ranged from small boats to sea-going merchantmen. This statistical fact supports the notion that three-hole composite anchors, though locally made and of 'secondary' quality, were used not only for small lighters and fishing boats but also for the long- range seaborne trade of the city. Such seaborne trade is also well attested by imported pottery, a considerable proportion of which came from Egypt (Arnon, 1996: 96).

As for such seaborne connection it is interesting to match the strange perforated stone shank found in a medieval context on the bed of the Intermediate Harbour Basin of Caesarea With those found at Alexandria (Nibbi, 1991: 185-188). Although they are not similar in shape, these two types of anchors have in common the two apertures that were pierced at right angles at both ends of the shank( Raban, 2000, 260-272). 
There was another type of anchor quite similar to the composite stone anchor which is the Sand anchor: Frost defines three varieties of pierced stone anchors: "sand anchors "are small, flat stones with additional holes for taking wooden pieces that function like the arms of the later wooden and metal anchors the stone's weight is minimal and is not an anchoring factor these anchors are particularly suited for grasping a sandy bottom. "Weight-anchors "have a single hole for the hawser; they anchor a craft solely by their weight these anchors may tend to drag on a flat and sandy bottom. "Composite-anchors "are heavier than sand-anchors but like them have additional piercings for one or two wooden "arms". These anchors hold the bottom with their weight and arms (Wachsmann, 1998:233) (Mc.Caslin1980, 18-20). 


\section{Reference:}

- Arnon, Y. D., 1996, The International Commercial Activity of Caesarea during the Early Islamic II Period (749-969 CE) According to the Ceramic Evidence, MA Thesis, University of Haifa (Hebrew, with English summary).

- Darvill, Timothy, and Geoffrey Wainwright. Stonehenge excavations 2008. The Antiquaries Journal 89 (2009): 1-19.

- Delgado, L. P. (Ed.), 1997, British Museum Encylopaedia of Underwater and Maritime Archaeology. London.

- Frost, H (1997) stone anchors: the need for methodical recording, Indian journal of history of science, 32(2).

- Frost, H (1997) stone anchors: the need for methodical recording, Indian journal of history of science, 32(2).

- Frost, H., 1970, Bronze Age stone anchors from the Eastern Mediterranean: dating and identification. MM, 56.4377-394

- J. A. TÓTH.2002, ActaArchaeologicaAcademiaeScientiarumHungaricae 53, 2002

- McCaslin, D. E., 1980, Stone Anchors in Antiquity: Coastal Settlements and Maritime Trade routes in the Eastern Mediterranean

- Muckelroy,k.,1978.Maritime archaeology: Cambridge university press

- Nibbi, A., 1991. Five stone anchors from Alexandria, IJNA, 20, pp. 185-194

- Raban ,2002 .The International Journal of Nautical Archaeology (2000) 29.2: 260-272 doi:10.1006/ijna.2000.0312

- Shaw, Joseph W. Two three - holed stone anchors from Kommos, Crete: their context, type and origin." International Journal of Nautical Archaeology 24.4 (1995): 279-291.

- Steffy, J.R (2006) wooden shipbuilding and the interpretation of shipwrecks .Texas A\&M University Press

- The Columbia Electronic Encyclopedia,2013, Columbia University Press. Available at 
http://encyclopedia2.thefreedictionary.com/Anchor \{accessed 8-6$2013\}$.

- Wachsmann, S., 1998, Seagoing Ships and Seamanship in the Bronze Age Levant. College Station, Texas. 


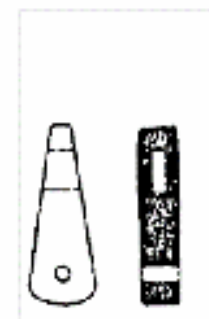

(a)

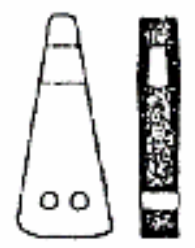

(b)

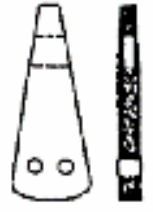

(c)

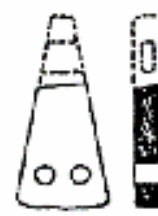

(d)

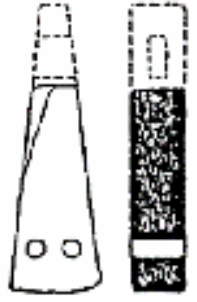

(c)

20

$100 \mathrm{~cm}$

Figure 1: small stone anchors used as a Wight for fishi rg ret $\mathrm{s} \sigma \boldsymbol{\Phi}$ a bal ance stone at the stormy water

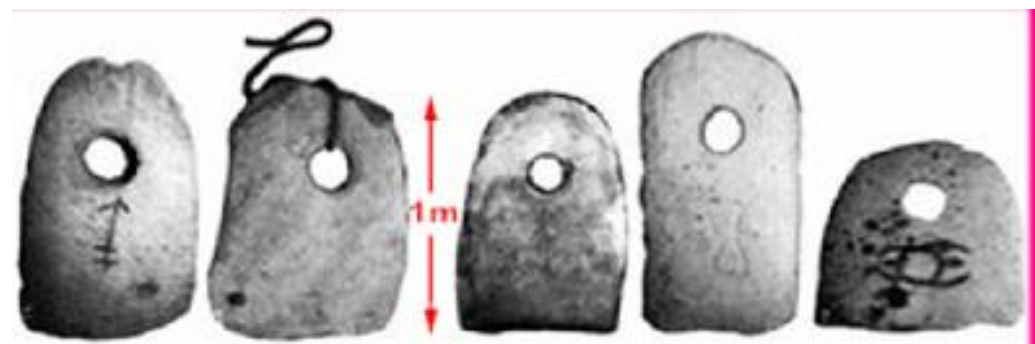

Anchor Stones from the Coast of Israel

(courtesy of David Fasold)

Figure 2:stone anchors with a single hole

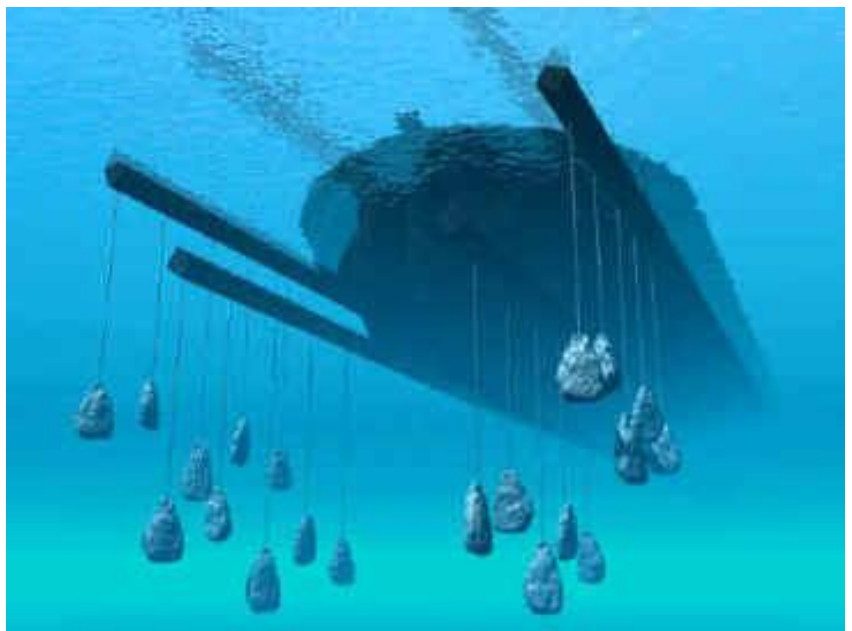

Figure 3: The stones would have been hung from the ark to stabilize it 


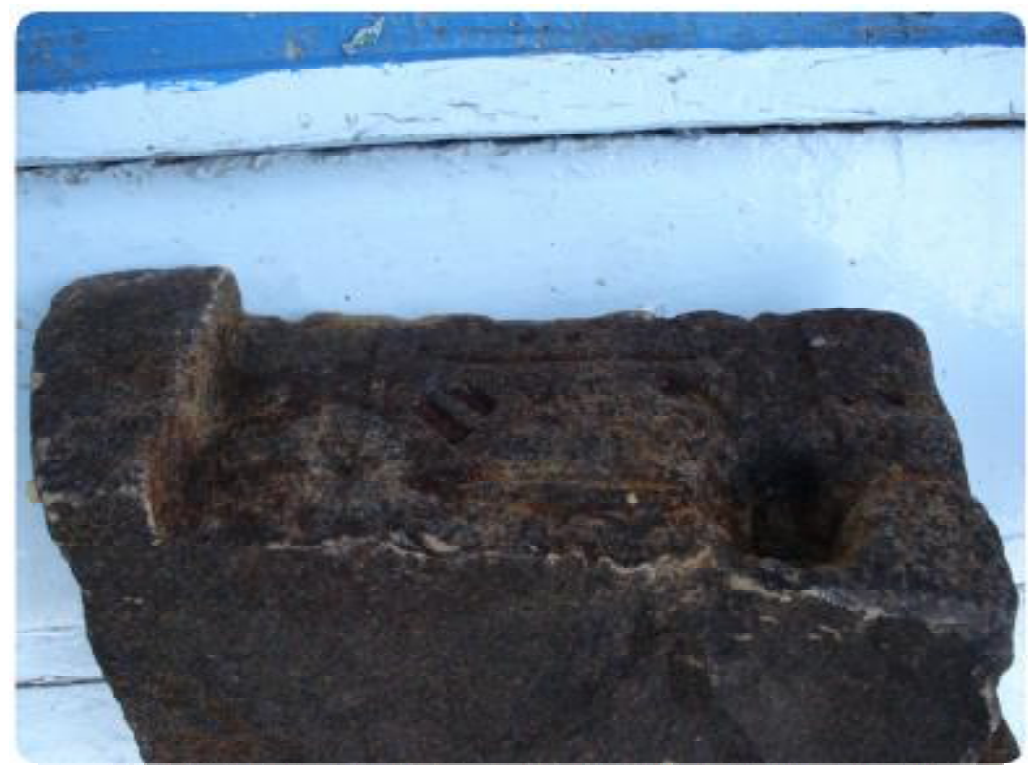

Figure4: a statue stone base had been reused as stone anchor, Aswan

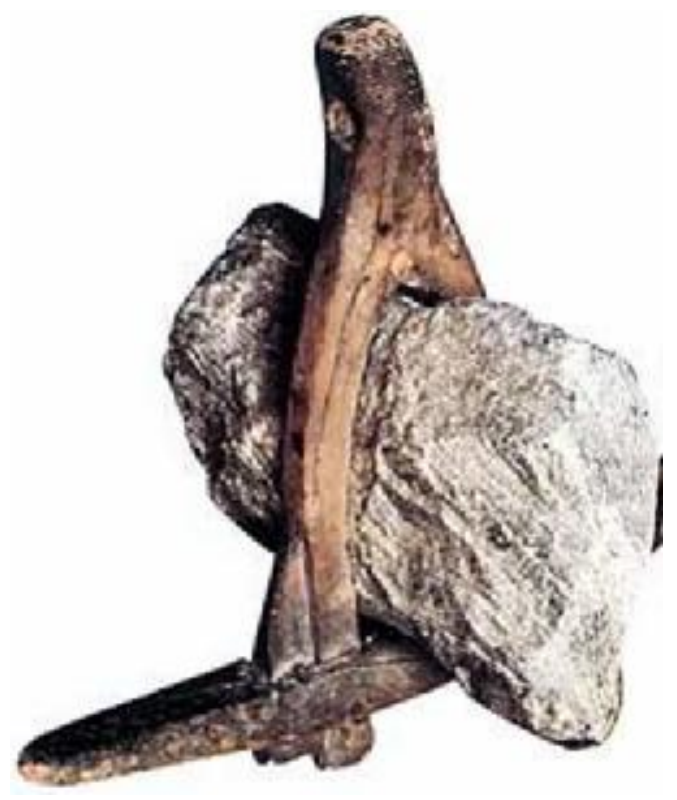

Figure 5 : Viking anchor 


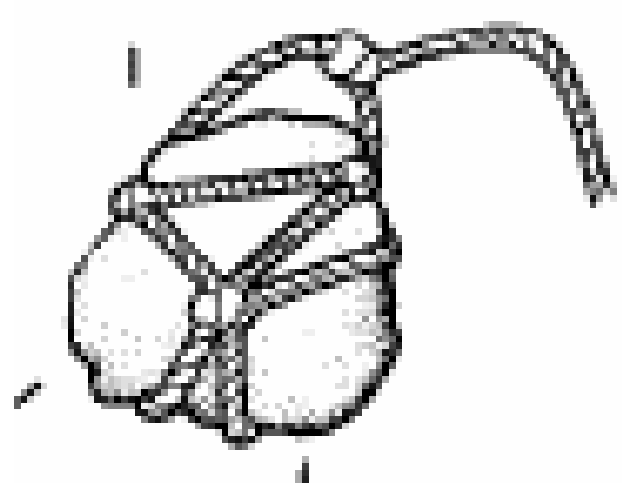

Figure 6 an early stone anchor

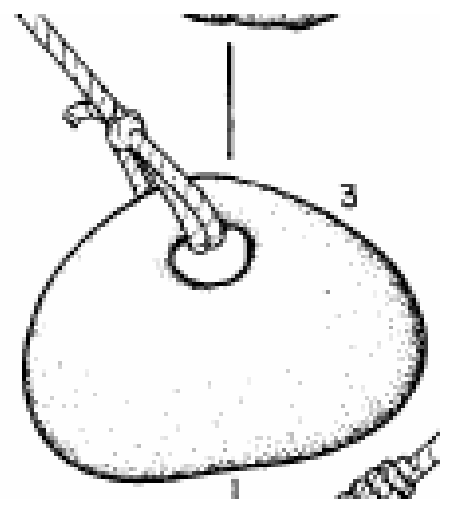

Figure 8 an oval stone anchor

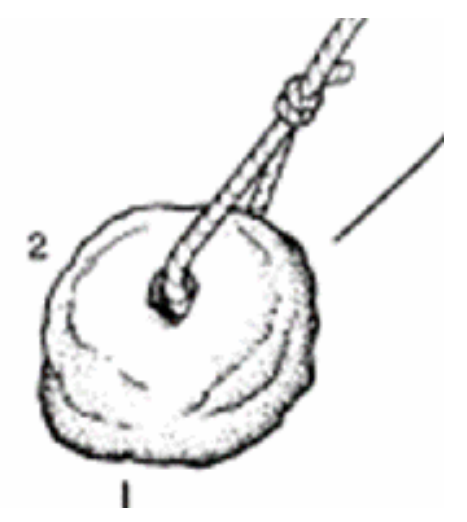

Figure 7 quren reused as nchor " anchor with a single hole in the middle"

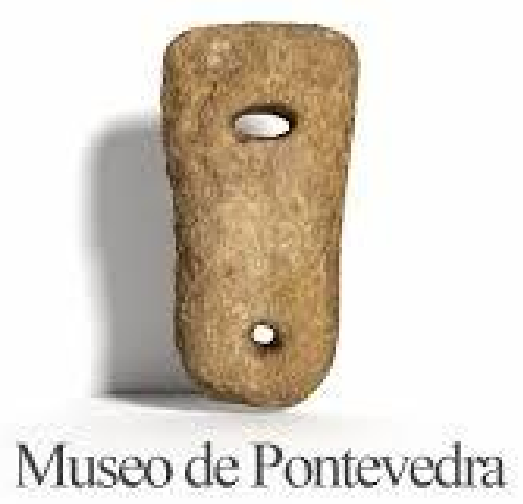

Figure 9: composite stone anchor "anchor with 3 holes" 

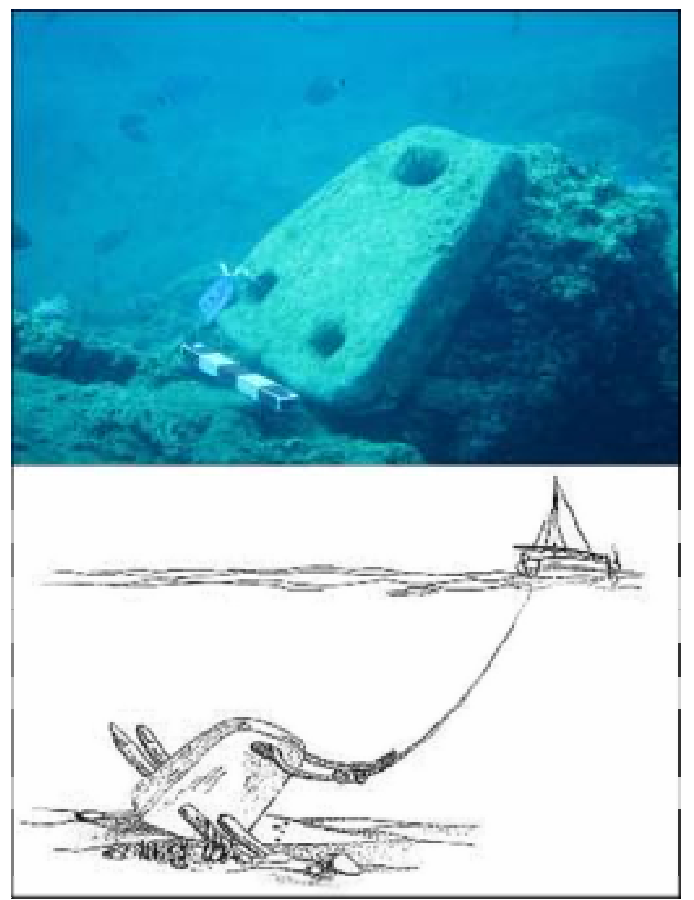

Figure 10: composite stone anchor "anchor with two holes"

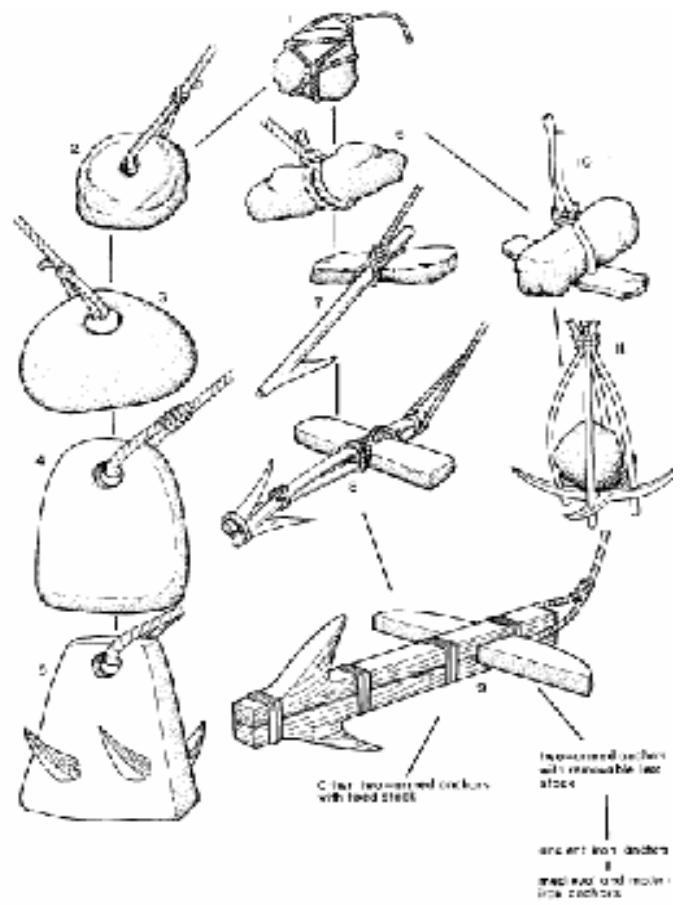

Figure 11 anchors development from the early stone anchor to the lead stock anchor 
PDF created with pdfFactory Pro trial version www.pdffactory.com 